\title{
The Effect of Body Mass Index on Acute Cardiometabolic Responses to Graded Exercise Testing in Children: A Narrative Review
}

\author{
Pantelis T. Nikolaidis ${ }^{1}$, Eleni Kintziou ${ }^{2}$, Georgios Georgoudis ${ }^{2}$, José Afonso ${ }^{3}$, \\ Rodrigo L. Vancini ${ }^{4}$ (D) and Beat Knechtle ${ }^{5, *(D)}$ \\ 1 Exercise Physiology Laboratory, 18450 Nikaia, Greece; pademil@hotmail.com \\ 2 School of Health Sciences, University of West Attica, 12243 Egaleo, Greece; ekintziou@teiath.gr (E.K.); \\ gg@hol.gr (G.G.) \\ 3 Faculty of Sport, University of Porto, 4200-450 Porto, Portugal; jafonsovolei@hotmail.com \\ 4 Center of Physical Education and Sport, Federal University of Espírito Santo, 29075-910 Vitória, Brazil; \\ rodrigoluizvancini@gmail.com \\ 5 Institute of Primary Care, University of Zurich, 9001 Zurich, Switzerland \\ * Correspondence: beat.knechtle@hispeed.ch; Tel.: +41-(0)-71-226-93-00
}

Received: 18 July 2018; Accepted: 18 September 2018; Published: 20 September 2018

\begin{abstract}
Although the beneficial role of exercise for health is widely recognized, it is not clear to what extent the acute physiological responses (e.g., heart rate $(\mathrm{HR})$ and oxygen uptake $\left(\mathrm{VO}_{2}\right)$ ) to a graded exercise test are influenced by nutritional status (i.e., overweight vs. normal-weight). Therefore, the main objectives of the present narrative review were to examine the effect of nutritional status on acute $\mathrm{HR}$, and $\mathrm{VO}_{2}$ responses of children to exercise testing. For this purpose, we examined existing literature using PubMed, ISI, Scopus, and Google Scholar search engines. Compared with their normal-body mass index (BMI) peers, a trend of higher $\mathrm{HR}_{\text {rest }}$, higher HR during submaximal exercise testing, and lower $\mathrm{HR}_{\max }$ was observed among overweight and obese children (according to $\mathrm{BMI}$ ). Independent from exercise mode (walking, running, cycling, or stepping), exercise testing was metabolically more demanding (i.e., higher $\mathrm{VO}_{2}$ ) for obese and overweight children than for their normal-weight peers. Considering these cardiometabolic differences according to BMI in children might help exercise specialists to evaluate the outcome of a graded exercise test (GXT) (e.g., $\mathrm{VO}_{2 \mathrm{max}}$ $\mathrm{HR}_{\max }$ ) and to prescribe optimal exercise intensity in the context of development of exercise programs for the management of body mass.
\end{abstract}

Keywords: body fat; cardiac rate; cycling; exercise intensity; heart rate; metabolism; overweight; respiratory quotient; resting metabolic rate

\section{Introduction}

It has been reported that more than half of adults in the USA are either overweight or obese, and that high levels of body mass (BM) or body fat percentage (BF) are associated with increased risk for numerous diseases [1]. High rates of combined overweight and obesity have also been recorded for children and adolescents, e.g., 20-25\% in Latin America [2], 40\% in southern Europe, and $10 \%$ in northern Europe [3]. In addition, obesity has been shown to be associated with increased chance of mortality [4], whereas overweight has been linked to diseases such as hypertension, hypercholesterolemia, and diabetes [5,6]. Overweight and obesity did not only have implications for health, but also had an important financial impact on increasing health care expenditures [7].

From a physiological point of view, an increased BM might result from an excess of energy availability, which in turn might result from either increased energy intake, decreased energy 
expenditure, or a combination of both. Consequently, most of the research concerning the management of overweight and obesity focused on altering either nutrition intake and/or exercise levels [8]. A review reported that interventions using both exercise and diet resulted in greater BM reduction than diet alone, and that the magnitude of BM reduction depended on exercise intensity, i.e., the higher the exercise intensity, the greater the BM reduction [8].

Thus, information on exercise intensity is crucial to develop efficient aerobic exercise interventions for overweight and obese children. Exercise intensity might be measured by oxygen consumption $\left(\mathrm{VO}_{2}\right)$, metabolic equivalents (METs), lactate concentration, rate of perceived exertion, and heart rate (HR) [9] during a graded exercise test (GXT). When HR is used to prescribe exercise intensity, training zones should be set taking into account resting $\left(\mathrm{HR}_{\text {rest }}\right)$ and maximal values of $H R\left(H R_{\max }\right)$, e.g., the Karvonen method [10], in which exercise intensity is expressed as a percentage of HR reserve. An alternative might be simply to express $\mathrm{HR}$ as a percentage of $\mathrm{HR}_{\max }$, which is an easy method to administer, but its weakness is in describing low intensities (e.g., $20 \%$ or $30 \%$ ).

Despite the importance of exercise intensity in intervention programs for overweight and obese children, and the acknowledgment of HR as a measure of exercise intensity, limited data existed concerning acute HR responses to exercise in these population groups. It might be of great practical value to be aware of differences in acute HR responses of these groups compared to their normal-weight counterparts, because this information would assumedly contribute to a better prescription of exercise intensity and subsequently better development of exercise interventions to manage overweight and obesity. For instance, potential differences in $\mathrm{HR}_{\max }$ by BMI (body mass index) during a GXT might influence the indirect criteria used to assess the attainment of $\mathrm{VO}_{2 \max }$.

\subsection{Nutritional Status and Body Mass Index}

Nutritional status reflects the energy balance, i.e., the relationship between energy intake (nutrition) and energy expenditure (basal metabolic rate, physical activity, and thermic effect of meals) [11]. Assessing BM for a given height (e.g., BMI) has been widely used as a measure of nutritional status. BMI has been used to classify adults as underweight $\left(<18.5 \mathrm{~kg} \cdot \mathrm{m}^{-2}\right)$, normal-weight $\left(18.5-25 \mathrm{~kg} \cdot \mathrm{m}^{-2}\right)$, overweight $\left(25-30 \mathrm{~kg} \cdot \mathrm{m}^{-2}\right)$, and obese $\left(>30 \mathrm{~kg} \cdot \mathrm{m}^{-2}\right)[12,13]$. According to this classification, BMI might be evaluated in children using centile curves that at age 18 years pass through the cut-off points used for adults $[14,15]$. However, there is not a unique definition for children. One possibility is to define those children with BMI higher than $85 \%$ as overweight [16], and those with BMI lower than the 10th percentile as lean [17]. Another study, which also used percentiles, defined those children with BMI higher than $95 \%$ as overweight [18], whereas Pate and colleagues [19] defined those with BMI lower than $85 \%$ as normal-weight, between $85 \%$ and $95 \%$ as being at risk for overweight, and those with BMI higher than $95 \%$ as overweight. On the contrary, those with BMI higher than $95 \%$ were defined as obese in other studies [20,21]. Based on percentiles, Reybrouck and colleagues [22] defined obesity as having a BM higher than $90 \%$ of the normal values when expressed on a BM for height diagram. Also, Sigmund and colleagues [23], and Govindan and colleagues [24] defined those with a BMI higher than $85 \%$ and $97 \%$ as overweight and obese, respectively. With regards to body composition, BMI does not provide information whether an excess of BM is due to BF or fat-free mass (FFM). Nevertheless, BMI is used as a proxy measure of BF due to their large correlation [25].

\subsection{Exercise Mode, Intensity, and Protocols}

Testing aerobic capacity usually takes place either in a laboratory setting or in the field. In a laboratory, exercise testing is performed on calibrated equipment, which might be a treadmill [22,26-29], a cycle ergometer [30-32], or a step [33-36], whereas in field testing, participants run a certain distance as fast as they can, e.g., 1 mile run/walk [37], or try to cover the longest distance within a given time, e.g., $12 \mathrm{~min}$ run/walk [18], or run with an incremental speed as much as they can, e.g., $20 \mathrm{~m}$ shuttle run test [17]. The tests conducted in field-where the environmental conditions 
(e.g., temperature, humidity, wind, and noise) vary and may interfere with the outcome-are less valid and reliable than those conducted in a laboratory [38-40].

Laboratory testing typically includes either maximal or submaximal protocols. An example of maximal protocol is the Bruce protocol [21], which is performed on a treadmill using incremental speed and incline. Maximal tests are also performed on a cycle ergometer [41,42]. On the contrary, submaximal testing does not require maximal effort; rather participants perform at given intensities, like running against $4,5.6$, and $8 \mathrm{~km} \cdot \mathrm{h}^{-1}$ on a treadmill $[16,26]$. An example of a submaximal test using a step (YMCA protocol) includes stepping up and down on a $30 \mathrm{~cm}$ step bench for $3 \mathrm{~min}$, in which HR is recorded with a stethoscope during the first minute of recovery after the test $[24,35]$. Another example of a similar protocol is the Queen's College step test, which includes stepping up and down for $3 \mathrm{~min}$ with the same frequency as in YMCA protocol $\left(24\right.$ ascends. $\left.\mathrm{min}^{-1}\right)$, but using a higher step bench $(41.3 \mathrm{~cm})[33,34]$. Pate and colleagues used a submaximal protocol on a treadmill consisting of two 3-min stages of different intensities.

It should be highlighted that the exercise mode might influence the differences in cardiometabolic responses between normal- and overweight participants in the studies under examination, because the body is supported on a cycle ergometer, in contrast to a treadmill or step, and this might attenuate the effect of BM. In this line, a study on a cycle ergometer reported similar cardiometabolic response to exercise between normal- and overweight children [30]. Furthermore, it has been shown that at similar levels of $\mathrm{HR}$, obese adolescents had had higher $\mathrm{VO}_{2}$, energy expenditure, and fat oxidation during exercise on a treadmill than on a cycle ergometer [43]. Another consideration in exercise testing is the inclusion of detailed standardized procedures in the protocols with regards to aspects such as familiarization with the testing procedures, guidelines about nutrition and rest prior to testing, as well as for recommended time-of-the-day for conducting the tests (to prevent diurnal variation) [44].

\subsection{Maximal Oxygen Uptake and Body Composition}

$\mathrm{VO}_{2 \max }$ has been considered as the golden criterion measure of aerobic capacity, which includes the recording of $\mathrm{VO}_{2}$ during a GXT usually on a treadmill or a cycle ergometer [45]. In addition to the standard measurement unit $\left(\mathrm{L} \cdot \mathrm{min}^{-1}\right)$, i.e., how much oxygen is transferred and consumed in the end of a maximal test, this measure has also been expressed relative to BM unit $\left(\mathrm{mL} \cdot \mathrm{kg}^{-1} \cdot \mathrm{min}^{-1}\right)$ in order to reflect the effect of body size on aerobic capacity [46]. Thus, caution is needed when examining studies on $\mathrm{VO}_{2 \max }$ to consider which measurement unit is being implemented ( $\mathrm{L} \cdot \mathrm{min}^{-1}$ or $\left.\mathrm{mL} \cdot \mathrm{kg}^{-1} \cdot \mathrm{min}^{-1}\right)$.

The use of relative units for $\mathrm{VO}_{2}$ depends on the applied model (atomic, molecular, cellular, tissue-system, and whole body) of body composition [47]. According to this classification of body composition, $\mathrm{VO}_{2}$ is scaled for $\mathrm{BM}$ when the whole body is considered. In addition to the traditional relative unit $\left(\mathrm{mL} \cdot \mathrm{min}^{-1} \cdot \mathrm{kg}^{-1}\right)$, another option is allometric scaling [48] suggesting a different consideration of BM, e.g., $\mathrm{mL} \cdot \mathrm{min}^{-1} \cdot \mathrm{kg}^{-0.67}, \mathrm{~mL} \cdot \mathrm{min}^{-1} \cdot \mathrm{kg}^{-0.71}$, or $\mathrm{mL} \cdot \mathrm{min}^{-1} \cdot \mathrm{kg}^{-0.75}$ instead of $\mathrm{mL} \cdot \mathrm{min}^{-1} \cdot \mathrm{kg}^{-1}[46,49]$. The rationale for the use of allometric scaling is that larger animals increase oxygen transport by having bigger hearts (stroke volume), whereas smaller animals achieve the same effect by increasing their heart rate to very high levels, as it has been indicated by the comparative physiology of animals of different sizes [50]. Moreover, $\mathrm{VO}_{2}$ can be scaled for FFM when the tissue-system level in the body composition classification is considered [51].

While the importance of exercise testing for the development of optimal training interventions for BM management is undisputable, there is no comprehensive review regarding differences in cardiometabolic responses by BMI groups during a GXT. Knowledge on such differences could be used by practitioners to design cohort-specific exercise testing protocols. Subsequently, data from these tests could be taken to deduce cardiorespiratory training zones. Therefore, the main aim of the present study was to examine the existing body of literature concerning cross-sectional studies that compared acute $\mathrm{HR}$ and $\mathrm{VO}_{2}$ responses to exercise during a GXT in groups differing for BMI. A further aim was to study differences according to BMI for other practically relevant cardiorespiratory parameters, such as 
$\mathrm{HR}_{\text {rest}}$, resting metabolic rate (RMR), and the respiratory quotient (RQ). Moreover, methodological issues concerning the exercise stimulus used in existing literature, such as exercise intensity (e.g., rest, submaximal, maximal, and recovery) and mode (e.g., running and cycling), were examined.

\section{Methods}

For the purpose of the present narrative review, we thoroughly examined existing literature using Scopus, PubMed, Google Scholar, and Clarivate Analytics search engines in December 2017. Keywords and syntaxes for the search engines were: "heart rate" OR "oxygen uptake" OR "resting metabolic rate" OR "respiratory quotient") AND ("body mass index" OR "nutritional status" OR normal-weight OR overweight OR obese) AND (children OR adolescents) NOT (adult OR women OR men). Inclusion criteria comprised studies $(n=71)$ that were published in English only. In addition, studies were eligible for inclusion if they reported data on age, sex, number of participants, BMI, exercise protocol, and HR, and use at least two groups differing in BMI for the purpose of cross-sectional design [52]. Any study that lacked one of the abovementioned elements was excluded from further analysis.

\section{Results and Discussion}

Our search identified 14 studies that applied cardiorespiratory exercise testing in children aged 6-18 years. Most studies $(n=8)$ were conducted in pre-pubertals and included both sexes. Unfortunately, these studies did not separate their findings according to sex. The remaining $(n=6)$ studies examined adolescents and reported sex-specific findings. Sample sizes ranged from 40 to 182 and whenever possible participants were classified in two groups (i.e., normal-weight versus overweight, normal-weight versus obese, or non-obese versus obese).

\subsection{Acute Oxygen Uptake Responses to Exercise Testing}

A large number of studies have shown higher absolute $\left(\mathrm{L} \cdot \mathrm{min}^{-1}\right)$ (Figure 1) and lower relative $\left(\mathrm{mL} \cdot \mathrm{kg}^{-1} \cdot \mathrm{min}^{-1}\right) \mathrm{VO}_{2 \max }$ (Figure 2$)$ in overweight or obese children compared with their normal-weight peers [53-55]. For instance, Goran and colleagues [53], and Marinov and colleagues [54] observed higher absolute and lower relative $\mathrm{VO}_{2 \max }$ for obese than for non-obese children. Moreover, Ruan and colleagues [55] observed higher absolute and lower relative $\mathrm{VO}_{2 \max }$ for overweight or obese than for non-obese school children. In agreement with these studies, Pate and colleagues [19] recorded differences among overweight, at risk for overweight, and normal-weight groups; $41.6,43.5$, and $48.2 \mathrm{~mL} \cdot \mathrm{kg}^{-1} \cdot \mathrm{min}^{-1}$ among boys, and $39.6,37.6$, and $35.9 \mathrm{~mL} \cdot \mathrm{kg}^{-1} \cdot \mathrm{min}^{-1}$ among girls, respectively.

\section{$\mathrm{VO}_{2}$ max in absolute values}

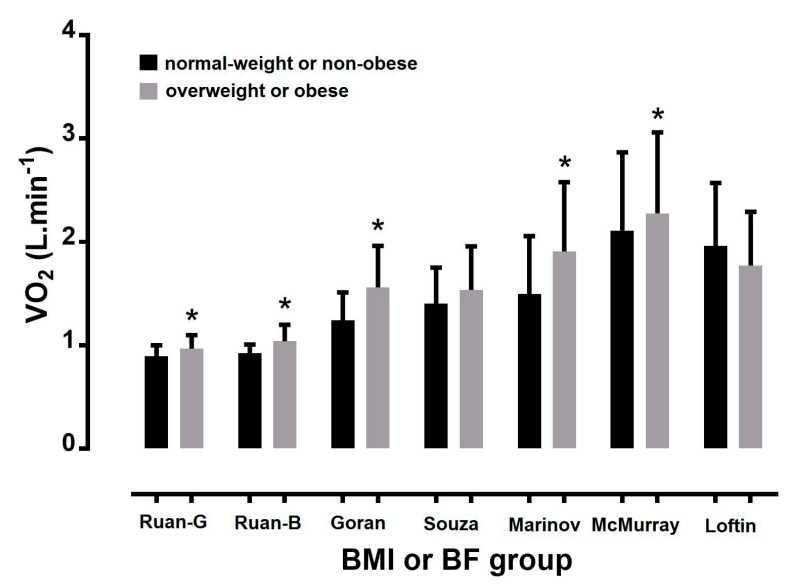

Figure 1. Maximal oxygen uptake in absolute values in normal-weight/non-obese and overweight/obese children. ${ }^{*} p<0.05$; study's first author name is presented in $\mathrm{x}$ axis; $\mathrm{G}=$ girls; $\mathrm{B}=$ boys; $\mathrm{BMI}=$ body mass index; $\mathrm{BF}=$ body fat percentage. 


\section{$\mathrm{VO}_{2}$ max in relative values}

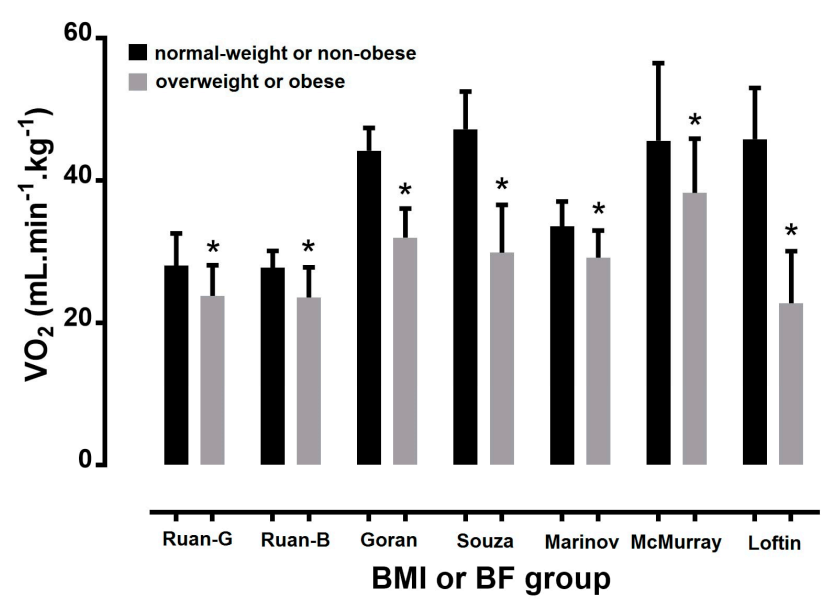

Figure 2. Maximal oxygen uptake in relative values in normal-weight/non-obese and overweight/obese children. ${ }^{*} p<0.05$; study's first author name is presented in $\mathrm{x}$ axis; $\mathrm{G}=$ girls; $\mathrm{B}=$ boys.

In the study of Souza and colleagues [21], although no statistical difference in absolute occurred between obese and normal-weight children, the former had lower relative than the latter. McMurray and colleagues [16] found higher $\mathrm{VO}_{2 \max }\left(\mathrm{L} \cdot \mathrm{min}^{-1}\right)$ for the overweight than for their normal-weight peers. Although Loftin and colleagues [56] showed similar values of $\mathrm{VO}_{2 \max }$ in $\mathrm{L} \cdot \mathrm{min}^{-1}$ between BMI groups, $\mathrm{VO}_{2 \max }$ in $\mathrm{mL} \cdot \mathrm{kg}^{-1} \cdot \mathrm{min}^{-1}$ was $50 \%$ lower for obese girls than their normal-weight peers.

\subsection{Relationship between Body Mass Index and Body Fat}

The negative effect of $\mathrm{BMI}$ on $\mathrm{VO}_{2 \max }$ should be partially attributed to the relationship between $\mathrm{BMI}$ and BF. The magnitude of this relationship in children ranged from large to very large depending on sex and ethnicity [57,58], very large [59] to almost perfect [60]. This close affinity between BMI and $\mathrm{BF}$ might explain the abovementioned observation that overweight children have higher $\mathrm{VO}_{2 \max }$ in absolute values but lower in relative to $\mathrm{BM}$ values than their normal-weight peers. On the contrary, overweight have lower relative $\mathrm{VO}_{2 \max }$ as their body composition is less metabolically active since it consists of a higher BF.

\subsection{Maximal Heart Rate and Heart Rate Acute Responses to Exercise Testing According to Body Mass Index}

Overweight had lower $\mathrm{HR}_{\max }$ than their normal-weight peers, both in a GXT on a cycle ergometer (186 vs. $196 \mathrm{bpm}$, respectively) or a walk/run test (175 vs. $197 \mathrm{bpm}$ ) in the study of Norman and colleagues [18] on 14-15 year-old children. Compared with non-obese, obese boys had higher acute HR response to Queen's College step test (171 vs. $150 \mathrm{bpm}$ ) [34], and the same trend was noticed in girls who performed the same test (176 vs. $155 \mathrm{bpm}$ ) [33]. Maffeis and colleagues [28] found higher acute HR responses to walking and running on a treadmill in obese than in non-obese children ( $~ 9$ years old); in addition, for a given exercise intensity, energy expenditure was also higher in obese than in non-obese, but it was comparable in the two groups when expressed in relation to BM values. On the contrary, Reybrouck and colleagues [22] found lower acute HR responses to exercise on a treadmill (i.e., normal vs. obese: 1st stage, 150 vs. 149 bpm; 2nd stage, 155 vs. 143 bpm; 3rd stage, 164 vs. 152 bpm; 4th stage, 172 vs. 162 bpm).

\subsection{Heart Rate at Rest}

$\mathrm{HR}_{\text {rest }}$ has been well discussed by many studies on overweight and obese children [18,20,24,61-64]. $\mathrm{HR}_{\text {rest }}$ in most of these studies has been measured in a seated position $[18,24,26,62,63,65]$, in a few studies in a supine position [61,64], and position was not reported in one case [20]. HR recording 
usually lasted from $3 \mathrm{~min}$ [24] to $15 \mathrm{~min}$ [61]. The equipment to assess $\mathrm{HR}_{\text {rest }}$ includes electrocardiograph $[18,64]$, blood pressure monitor [24,26,62,65], and HR monitor [61,63]. With regards to the role of BF, Govindan and colleagues [24] found that obese children had higher HR $\mathrm{H}_{\text {rest }}$ than non-obese children among both boys ( $84.3 \mathrm{vs.} 79.8 \mathrm{bpm}$, respectively) and girls ( $84.5 \mathrm{vs.} 81.3 \mathrm{bpm}$ ). Charakida and colleagues [62] observed that overweight and obese children (10.5 years) had higher $\mathrm{HR}_{\text {rest }}$ than their normal-weight peers $(72.4,74.6$ and $71.7 \mathrm{bpm}$, respectively). Norman and colleagues [18] found $\mathrm{HR}_{\text {rest }}$ to be higher in overweight ( $94 \mathrm{vs.} 82 \mathrm{bpm}$ ) than in normal-weight children (14.5 years). Faria and colleagues [20] showed higher $\mathrm{HR}_{\text {rest }}$ in obese children than in normal-weight children for girls (78.1 vs. $74.6 \mathrm{bpm}$, respectively), but not for boys (73.3 vs. $73.6 \mathrm{bpm}$ ). There was only one study that did not record differences between overweight and normal-weight children for boys ( $81 \mathrm{vs.} 80 \mathrm{bpm}$, respectively) or for girls (93 vs. $93 \mathrm{bpm}$ ) [65]. In addition to the abovementioned studies of cross-sectional design, another experimental approach was to examine the effect of an intervention exercise program on HR to exercise.

\subsection{Sport Populations}

Recent studies investigated differences in aerobic capacity between normal and overweight athletes [66-71]. Aerobic capacity was estimated by two tests: (a) physical working capacity test in $\mathrm{HR} 170 \mathrm{bpm}\left(\mathrm{PWC}_{170}\right)$ conducted on a cycle ergometer, in which power relative to $\mathrm{BM}\left(\mathrm{W} \cdot \mathrm{kg}^{-1}\right)$ was recorded, and (b) a 3 min step test, in which acute HR responses were recorded at the end of the test and at the end of the first minute of recovery. In a study on male handball players (15 years), normal-weight had similar $\mathrm{PWC}_{170}\left(2.59\right.$ vs. $2.52 \mathrm{~W} \cdot \mathrm{kg}^{-1}$, respectively), HR at the end of the step test (140 vs. $145 \mathrm{bpm}$ ) and at the end of the first minute of recovery ( $96 \mathrm{vs} .99 \mathrm{bpm})$ than their overweight peers [70]. In research on male soccer players (12-21 years), normal-weight athletes had lower $\mathrm{PWC}_{170}$ in $\mathrm{W}$ and higher $\mathrm{PWC}_{170}$ in $\mathrm{W} \cdot \mathrm{kg}^{-1}$ than their overweight counterparts [69]. In addition, a study on female volleyball players (15 years) revealed similar $\mathrm{PWC}_{170}$ in $\mathrm{W} \cdot \mathrm{kg}^{-1}$ for normal-weight and overweight participants (1.97 vs. $1.84 \mathrm{~W} \cdot \mathrm{kg}^{-1}$, respectively) [67]. The protocol of $\mathrm{PWC}_{170}$ consisted of submaximal cycling against predetermined resistances for three 3 min stages aiming to elicit HR between 120 and $170 \mathrm{bpm}$. Thus, the performance in $\mathrm{PWC}_{170}$ was dependent of HR; i.e., the lower the $\mathrm{HR}$ response to a given exercise intensity, the higher the $\mathrm{PWC}_{170}$. Consequently, the relatively low performance of overweight athletes in $\mathrm{PWC}_{170}$ might reflect their relatively high acute $\mathrm{HR}$ responses.

\subsection{Resting Metabolic Rate}

RMR, usually measured by indirect calorimetry, is a major determinant of the daily total energy expenditure, and therefore, it is considered as a target-variable in any BM management program [72,73]. It has been observed that overweight boys had higher RMR than their normal-weight peers by $30 \%$ in a study where these two groups differed by $51 \%$ in BM [72]. A research on girls and boys reported 15\% higher RMR and 45\% higher BM in overweight children than their normal-weight peers [74]. It was also shown that overweight girls and boys had 11\% higher RMR and 51\% higher BM than their normal-weight peers [75]. Since RMR correlates with FFM and BM, RMR was disproportionately different from BM [75], the higher RMR in overweight children should be attributed mostly to their higher BM compared to their normal-weight peers.

\subsection{Respiratory Quotient}

Indirect calorimetry also provides information about the nutrients' (carbohydrates, lipids, and protein) oxidation, which can be quantified using the RQ, i.e., the ratio of the carbon dioxide removed from the body divided by the oxygen consumed in the tissues [76]. Typical values of RQ range from 0.7 (lipid oxidation) to 1.0 (carbohydrate oxidation); thus, the estimation of RQ for a given exercise characterizes the substrate oxidation [30]. A comparison of BMI groups showed no difference in lipid oxidation during various submaximal loads of a GXT in prepubescent girls, but higher lipid oxidation 
in obese pubescent girls [77]. However, no difference in RQ was observed between normal-weight and overweight boys [30].

\subsection{Limitations, Strengths, and Practical Applications}

It should be highlighted that, although all ethnicities were considered during the search in the databases, it was acknowledged that most studies were conducted in Caucasian populations. With regards to ethnicity, differences have been observed in body composition and energy expenditure among ethnic groups (South Asian, East Asian, Southeast Asian, and Pacific Islanders) [78]. Moreover, BMI of Pacific Islanders was higher and their rate of physical growth more rapid compared to people of European descent living in the same country [79]. Thus, the findings of the present study should be generalized with caution to non-Caucasian ethnicities. In addition, it should be noted that maturation level was not considered in most of the existing research and this might also influence the outcome of the studies under examination. For instance, an elevated BMI has been associated with earlier puberty, especially in girls, and the relationship between BMI and onset of puberty might be influenced by biological (e.g., hormones) and environmental factors [80]. Most of the existing literature on acute HR responses to exercise among adults differing in BMI has obtained its data through maximal exercise testing, whereas most of the studies of cardiorespiratory fitness in BMI groups of children relied on field methods such as shuttle run endurance tests, and did not provide information about $\mathrm{HR}$ or $\mathrm{VO}_{2}$ variation [81,82]. Therefore, the need for studies comparing groups differing in BMI using submaximal exercise intensities, which characterize typical exercise training and longitudinal design was identified. The knowledge of acute cardiometabolic responses of various BMI groups to exercise testing might help practitioners to develop optimal exercise programs for BM management for overweight and obese children. In addition, our findings provided practical applications for practitioners engaged in exercise testing. Notably, caution is needed when interpreting $\mathrm{VO}_{2 \max }$ in the examined cohorts. Furthermore, it would be recommended for strength and conditioning coaches prescribing exercise that aerobic exercise should be less (in terms of duration and/or intensity) in overweight and obese children and adolescents than in their normal-weight peers in order to induce similar cardiometabolic acute responses. We were able to show that different measurement units (e.g., absolute versus relative to $\mathrm{BM}$ ) influence the variation of $\mathrm{VO}_{2 \max }$ according to BMI. Furthermore, since overweight children achieved lower $\mathrm{HR}_{\max }$ during GXT than their normal-weight peers, this should be considered in the evaluation of the indirect criteria used to assess the attainment of $\mathrm{VO}_{2 \max }$.

\section{Conclusions}

Compared with their normal-weight peers, a trend of higher $\mathrm{HR}_{\text {rest }}$ and $\mathrm{HR}$ during submaximal exercise and lower $\mathrm{HR}_{\max }$ was observed among overweight and obese children. Independent from exercise mode (walking, running, cycling, or stepping), exercise was metabolically more demanding for obese and overweight children than for their normal-weight peers. Findings from this study are of practical relevance for practitioners working in the field of cardiorespiratory exercise testing in youth. Test data can be used to develop adequate training programs for BM management in youth. Based on the findings of this review, strength and conditioning coaches working with children and adolescents varying for $\mathrm{BM}$ and $\mathrm{BF}$ should be aware about the increased cardiometabolic cost induced by aerobic exercise in those being overweight or obese compared to their normal-weight peers.

Author Contributions: P.T.N., E.K., G.G., J.A., R.L.V. and B.K. are the authors of this manuscript and take responsibility for the accuracy of its content.

Acknowledgments: We thank Patricia Villiger for her help with English editing.

Conflicts of Interest: The authors declare no conflict of interest. 


\section{Abbreviations}

$\begin{array}{ll}\text { BF } & \text { body fat percentage } \\ \text { bpm } & \text { beats per minute } \\ \text { DBP } & \text { diastolic blood pressure } \\ \text { FFM } & \text { fat-free mass } \\ \text { GXT } & \text { graded exercise test } \\ \mathrm{HR} & \text { heart rate } \\ \mathrm{HR}_{\max } & \text { maximal heart rate } \\ \mathrm{HR}_{\text {rest }} & \text { heart rate at rest } \\ \mathrm{METs} & \text { metabolic equivalents } \\ \mathrm{PE} & \text { Physical Education } \\ \mathrm{PWC}_{170} & \text { physical working capacity test in HR } 170 \mathrm{bpm} \\ \mathrm{RMR} & \text { resting metabolic rate } \\ \mathrm{RQ} & \text { respiratory quotient } \\ \mathrm{RPE}_{\mathrm{SBP}} & \text { rate of perceived exertion } \\ \mathrm{VO}_{2} & \text { systolic blood pressure } \\ \mathrm{VO}_{2 \mathrm{max}} & \text { oxygen uptake } \\ \end{array}$

\section{References}

1. Yanovski, S.Z. Overweight, obesity, and health risk: National task force on the prevention and treatment of obesity. Arch. Intern. Med. 2000, 160, 898-904.

2. Rivera, J.A.; De Cossío, T.G.; Pedraza, L.S.; Aburto, T.C.; Sánchez, T.G.; Martorell, R. Childhood and adolescent overweight and obesity in latin america: A systematic review. Lancet Diabetes Endocrinol. 2014, 2, 321-332. [CrossRef]

3. Ahrens, W.; Pigeot, I.; Pohlabeln, H.; De Henauw, S.; Lissner, L.; Molnár, D.; Moreno, L.A.; Tornaritis, M.; Veidebaum, T.; Siani, A.; et al. Prevalence of overweight and obesity in european children below the age of 10. Int. J. Obes. 2014, 38, S99-S107. [CrossRef] [PubMed]

4. Flegal, K.M.; Graubard, B.I.; Williamson, D.F.; Gail, M.H. Excess deaths associated with underweight, overweight, and obesity. J. Am. Med. Assoc. 2005, 293, 1861-1867. [CrossRef] [PubMed]

5. Kouvari, M.; Chrysohoou, C.; Tsiamis, E.; Kosyfa, H.; Kalogirou, L.; Filippou, A.; Iosifidis, S.; Aggelopoulos, P.; Pitsavos, C.; Tousoulis, D. The "overweight paradox" in the prognosis of acute coronary syndrome for patients with heart failure-a truth for all? A 10-year follow-up study. Maturitas 2017, 102, 6-12. [CrossRef] [PubMed]

6. Van Itallie, T.B. Health implications of overweight and obesity in the united states. Ann. Intern. Med. 1985, 103, 983-988. [CrossRef] [PubMed]

7. Yang, Z.; Hall, A.G. The financial burden of overweight and obesity among elderly americans: The dynamics of weight, longevity, and health care cost. Health Serv. Res. 2008, 43, 849-868. [CrossRef] [PubMed]

8. Shaw, K.; Gennat, H.; O’Rourke, P.; Del Mar, C. Exercise for overweight or obesity. Cochrane Database Syst. Rev. 2006. [CrossRef] [PubMed]

9. Emerenziani, G.P.; Migliaccio, S.; Gallotta, M.C.; Lenzi, A.; Baldari, C.; Guidetti, L. Physical exercise intensity prescription to improve health and fitness in overweight and obese subjects: A review of the literature. Health 2013, 5, 113-121. [CrossRef]

10. Karvonen, M.J.; Kentala, E.; Mustala, O. The effects of training on heart rate; a longitudinal study. Ann. Med. Exp. Biol. Fenn. 1957, 35, 307-315. [PubMed]

11. Buhendwa, R.A.; Roelants, M.; Thomis, M.; Nkiama, C.E. Nutritional status and height, weight and bmi centiles of school-aged children and adolescents of 6-18-years from kinshasa (DRC). Ann. Hum. Biol. 2017, 44, 554-561. [CrossRef] [PubMed]

12. Garrido-Miguel, M.; Cavero-Redondo, I.; Alvarez-Bueno, C.; Rodriguez-Artalejo, F.; Moreno Aznar, L.; Ruiz, J.R.; Martinez-Vizcaino, V. Prevalence and trends of thinness, overweight and obesity among children and adolescents aged 3-18 years across europe: A protocol for a systematic review and meta-analysis. BMJ Open 2017, 7. [CrossRef] 
13. World Health Organization (WHO). Obesity: Preventing and Managing the Global Epidemic. Report of a Who Consultation; WHO: Geneva, Switzerland, 1998.

14. Cole, T.J.; Bellizzi, M.C.; Flegal, K.M.; Dietz, W.H. Establishing a standard definition for child overweight and obesity worldwide: International survey. BMJ 2000, 320, 1240-1243. [CrossRef] [PubMed]

15. Dietz, W.H.; Robinson, T.N. Use of the body mass index (BMI) as a measure of overweight in children and adolescents. J. Pediatr. 1998, 132, 191-193. [PubMed]

16. McMurray, R.G.; Ondrak, K.S. Effects of being overweight on ventilatory dynamics of youth at rest and during exercise. Eur. J. Appl. Physiol. 2011, 111, 285-292. [CrossRef] [PubMed]

17. Bovet, P.; Auguste, R.; Burdette, H. Strong inverse association between physical fitness and overweight in adolescents: A large school-based survey. Int. J. Behav. Nutr. Phys. Act. 2007, 4. [CrossRef] [PubMed]

18. Norman, A.C.; Drinkard, B.; McDuffie, J.R.; Ghorbani, S.; Yanoff, L.B.; Yanovski, J.A. Influence of excess adiposity on exercise fitness and performance in overweight children and adolescents. Pediatrics 2005, 115, e690-e696. [CrossRef] [PubMed]

19. Pate, R.R.; Wang, C.Y.; Dowda, M.; Farrell, S.W.; O’Neill, J.R. Cardiorespiratory fitness levels among us youth 12 to 19 years of age: Findings from the 1999-2002 national health and nutrition examination survey. Arch. Pediatr. Adolesc. Med. 2006, 160, 1005-1012. [CrossRef] [PubMed]

20. Faria, A.G.; Ribeiro, M.A.G.O.; Marson, F.A.L.; Schivinski, C.I.S.; Severino, S.D.; Ribeiro, J.D.; Barros Filho, A.A. Effect of exercise test on pulmonary function of obese adolescents. J. Pediatr. 2014, 90, 242-249. [CrossRef] [PubMed]

21. Souza, M.S.F.; Cardoso, A.L.; Yasbek, P., Jr.; Faintuch, J. Aerobic endurance, energy expenditure, and serum leptin response in obese, sedentary, prepubertal children and adolescents participating in a short-term treadmill protocol. Nutrition 2004, 20, 900-904. [CrossRef] [PubMed]

22. Reybrouck, T.; Weymans, M.; Vinckx, J.; Stijns, H.; Vanderschueren-Lodeweyckx, M. Cardiorespiratory function during exercise in obese children. Acta Paediatr. Scand. 1987, 76, 342-348. [CrossRef] [PubMed]

23. Sigmund, E.; Sigmundová, D.; Šnoblová, R.; Gecková, A.M. Actitrainer-determined segmented moderate-to-vigorous physical activity patterns among normal-weight and overweight-to-obese czech schoolchildren. Eur. J. Pediatr. 2014, 173, 321-329. [CrossRef] [PubMed]

24. Govindan, M.; Gurm, R.; Mohan, S.; Kline-Rogers, E.; Corriveau, N.; Goldberg, C.; Du Russel-Weston, J.; Eagle, K.A.; Jackson, E.A. Gender differences in physiologic markers and health behaviors associated with childhood obesity. Pediatrics 2013, 132, 468-474. [CrossRef] [PubMed]

25. Martin-Calvo, N.; Moreno-Galarraga, L.; Martinez-Gonzalez, M.A. Association between body mass index, waist-to-height ratio and adiposity in children: A systematic review and meta-analysis. Nutrients 2016, 8. [CrossRef] [PubMed]

26. Antoniades, O.G.; Douda, H.T.; Papazoglou, D.A.; Tokmakidis, S.P. The immediate adaptations to aerobic exercise of the cardiovascular function of overweight/obese pre-pubertal children. Arch. Hell. Med. 2014, 31, 477-486.

27. Breithaupt, P.G.; Colley, R.C.; Adamo, K.B. Using the oxygen uptake efficiency slope as an indicator of cardiorespiratory fitness in the obese pediatric population. Pediatr. Exerc. Sci. 2012, 24, 357-368. [CrossRef] [PubMed]

28. Maffeis, C.; Schutz, Y.; Schena, F.; Zaffanello, M.; Pinelli, L. Energy expenditure during walking and running in obese and nonobese prepubertal children. J. Pediatr. 1993, 123, 193-199. [CrossRef]

29. Reybrouck, T.; Mertens, L.; Schepers, D.; Vinckx, J.; Gewillig, M. Assessment of cardiorespiratory exercise function in obese children and adolescents by body mass-independent parameters. Eur. J. Appl. Physiol. Occup. Physiol. 1997, 75, 478-483. [CrossRef] [PubMed]

30. Maclejczyk, M.; Szymura, J.; Gradek, J.; Cempla, J.; Więcek, M. Physiological response is similar in overweight and normoweight boys during cycling: A longitudinal study. Acta Physiol. Hung. 2014, 101, 236-249. [CrossRef] [PubMed]

31. Rowland, T.; Bhargava, R.; Parslow, D.; Heptulla, R.A. Cardiac response to progressive cycle exercise in moderately obese adolescent females. J. Adoles. Health 2003, 32, 422-427. [CrossRef]

32. Unnithan, V.B.; Baynard, T.; Potter, C.R.; Barker, P.; Heffernan, K.S.; Kelly, E.; Yates, G.; Fernhall, B. An exploratory study of cardiac function and oxygen uptake during cycle ergometry in overweight children. Obesity 2007, 15, 2673-2682. [CrossRef] [PubMed]

33. Bandyopadhyay, A. Cardiorespiratory fitness in obese girls. Indian J. Physiol. Pharmacol. 2012, 56, 393-395. 
34. Chatterjee, S.; Chatterjee, P.; Bandyopadhyay, A. Cardiorespiratory fitness of obese boys. Indian J. Physiol. Pharmacol. 2005, 49, 353-357. [PubMed]

35. Gutin, B.; Yin, Z.; Johnson, M.; Barbeau, P. Preliminary findings of the effect of a 3-year after-school physical activity intervention on fitness and body fat: The medical college of georgia fitkid project. Int. J. Pediatr. Obes. 2008, 3, 3-9. [CrossRef] [PubMed]

36. Moore, J.B.; Beets, M.W.; Barr-Anderson, D.J.; Evenson, K.R. Sedentary time and vigorous physical activity are independently associated with cardiorespiratory fitness in middle school youth. J. Sports Sci. 2013, 31, 1520-1525. [CrossRef] [PubMed]

37. Mastrangelo, M.A.; Chaloupka, E.C.; Rattigan, P. Cardiovascular fitness in obese versus nonobese 8-11-year-old boys and girls. Res. Q. Exerc. Sport 2008, 79, 356-362. [CrossRef] [PubMed]

38. Lim, W.; Lambrick, D.; Mauger, A.R.; Woolley, B.; Faulkner, J. The effect of trial familiarisation on the validity and reproducibility of a field-based self-paced $\mathrm{VO}_{2 \max }$ test. Biol. Sport 2016, 33, 269-275. [CrossRef] [PubMed]

39. Cao, Z.B.; Miyatake, N.; Aoyama, T.; Higuchi, M.; Tabata, I. Prediction of maximal oxygen uptake from a 3-minute walk based on gender, age, and body composition. J. Phys. Act. Health 2013, 10, 280-287. [CrossRef] [PubMed]

40. Penry, J.T.; Wilcox, A.R.; Yun, J. Validity and reliability analysis of cooper's 12-minute run and the multistage shuttle run in healthy adults. J. Strength Cond. Res. 2011, 25, 597-605. [CrossRef] [PubMed]

41. Lintu, N.; Tompuri, T.; Viitasalo, A.; Soininen, S.; Laitinen, T.; Savonen, K.; Lindi, V.; Lakka, T.A. Cardiovascular fitness and haemodynamic responses to maximal cycle ergometer exercise test in children 6-8 years of age. J. Sports Sci. 2014, 32, 652-659. [CrossRef] [PubMed]

42. Potter, C.R.; Zakrzewski, J.K.; Draper, S.B.; Unnithan, V.B. The oxygen uptake kinetic response to moderate intensity exercise in overweight and non-overweight children. Int. J. Obes. 2013, 37, 101-106. [CrossRef] [PubMed]

43. Lafortuna, C.L.; Lazzer, S.; Agosti, F.; Busti, C.; Galli, R.; Mazzilli, G.; Sartorio, A. Metabolic responses to submaximal treadmill walking and cycle ergometer pedalling in obese adolescents. Scand. J. Med. Sci. Sports 2010, 20, 630-637. [CrossRef] [PubMed]

44. Vrbik, I.; Sporis, G.; Stefan, L.; Madic, D.; Trajkovic, N.; Valantine, I.; Milanovic, Z. The influence of familiarization on physical fitness test results in primary school-aged children. Pediatr. Exerc. Sci 2017, 29, 278-284. [CrossRef] [PubMed]

45. Bhati, P.; Bansal, V.; Moiz, J.A. Comparison of different volumes of high intensity interval training on cardiac autonomic function in sedentary young women. Int. J. Adoles. Med. Health 2017. [CrossRef] [PubMed]

46. Dencker, M.; Bugge, A.; Hermansen, B.; Froberg, K.; Andersen, L.B. Aerobic fitness in prepubertal children according to level of body fat. Acta Paediatr. 2010, 99, 1854-1860. [CrossRef] [PubMed]

47. Wang, Z.M.; Pierson, R.N., Jr.; Heymsfield, S.B. The five-level model: A new approach to organizing body-composition research. Am. J. Clin. Nutr. 1992, 56, 19-28. [CrossRef] [PubMed]

48. Loftin, M.; Sothern, M.; Abe, T.; Bonis, M. Expression of $\mathrm{VO}_{2 \text { peak }}$ in children and youth, with special reference to allometric scaling. Sports Med. 2016, 46, 1451-1460. [CrossRef] [PubMed]

49. McMurray, R.G.; Butte, N.F.; Crouter, S.E.; Trost, S.G.; Pfeiffer, K.A.; Bassett, D.R.; Puyau, M.R.; Berrigan, D.; Watson, K.B.; Fulton, J.E. Exploring metrics to express energy expenditure of physical activity in youth. PLoS ONE 2015, 10. [CrossRef] [PubMed]

50. Bassett, D.R., Jr.; Howley, E.T. Limiting factors for maximum oxygen uptake and determinants of endurance performance. Med. Sci. Sports Exerc. 2000, 32, 70-84. [CrossRef] [PubMed]

51. Dencker, M.; Wollmer, P.; Karlsson, M.K.; Linden, C.; Andersen, L.B.; Thorsson, O. Body fat, abdominal fat and body fat distribution related to $\mathrm{VO}(2$ peak $)$ in young children. Int. J. Pediatr. Obes. 2011, 6, e597-e602. [CrossRef] [PubMed]

52. Moher, D.; Liberati, A.; Tetzlaff, J.; Altman, D.G.; Group, T.P. Preferred reporting items for systematic reviews and meta-analyses: The prisma statement. PLoS Med. 2009, 6. [CrossRef] [PubMed]

53. Goran, M.I.; Fields, D.A.; Hunter, G.R.; Herd, S.L.; Weinsier, R.L. Total body fat does not influence maximal aerobic capacity. Int. J. Obes. 2000, 24, 841-848. [CrossRef]

54. Marinov, B.; Kostianev, S.; Turnovska, T. Ventilatory efficiency and rate of perceived exertion in obese and non-obese children performing standardized exercise. Clin. Physiol. Funct. Imaging 2002, 22, 254-260. [CrossRef] [PubMed] 
55. Ruan, H.; Tang, Q.; Zhao, X.; Cai, W. Relationship between aerobic capacity and body composition in school-aged children. Chin. J. Clin. Nutr. 2014, 22, 234-238.

56. Loftin, M.; Sothern, M.; Trosclair, L.; O'Hanlon, A.; Miller, J.; Udall, J. Scaling vo2 peak in obese and non-obese girls. Obes. Res. 2001, 9, 290-296. [CrossRef] [PubMed]

57. Liu, A.; Byrne, N.M.; Kagawa, M.; Ma, G.; Poh, B.K.; Ismail, M.N.; Kijboonchoo, K.; Nasreddine, L.; Trinidad, T.P.; Hills, A.P. Ethnic differences in the relationship between body mass index and percentage body fat among asian children from different backgrounds. Br. J. Nutr. 2011, 106, 1390-1397. [CrossRef] [PubMed]

58. Srdić, B.; Obradović, B.; Dimitrić, G.; Stokić, E.; Babović, S.S. Relationship between body mass index and body fat in children-Age and gender differences. Obes. Res. Clin. Pract. 2012, 6, e167-e173. [CrossRef] [PubMed]

59. Aeberli, I.; Gut-Knabenhans, M.; Kusche-Ammann, R.S.; Molinari, L.; Zimmermann, M.B. A composite score combining waist circumference and body mass index more accurately predicts body fat percentage in 6- to 13-year-old children. Eur. J. Nutr. 2013, 52, 247-253. [CrossRef] [PubMed]

60. Zhao, D.; Zhang, Y. Body mass index (BMI) predicts percent body fat better than body adiposity index (BAI) in school children. Anthropol. Anz. Ber. Über Die Biol. Anthropol. Lit. 2015, 72, 257-262. [CrossRef] [PubMed]

61. Birch, S.L.; Duncan, M.J.; Franklin, C. Overweight and reduced heart rate variability in british children: An exploratory study. Prev. Med. 2012, 55, 430-432. [CrossRef] [PubMed]

62. Charakida, M.; Jones, A.; Falaschetti, E.; Khan, T.; Finer, N.; Sattar, N.; Hingorani, A.; Lawlor, D.A.; Smith, G.D.; Deanfield, J.E. Childhood obesity and vascular phenotypes: A population study. J. Am. Coll. Cardiol. 2012, 60, 2643-2650. [CrossRef] [PubMed]

63. Da Silva, D.F.; Bianchini, J.A.A.; Antonini, V.D.S.; Hermoso, D.A.M.; Lopera, C.A.; Pagan, B.G.M.; McNeil, J.; Nardo, N., Jr. Parasympathetic cardiac activity is associated with cardiorespiratory fitness in overweight and obese adolescents. Pediatr. Cardiol. 2014, 35, 684-690. [CrossRef] [PubMed]

64. Sun, G.Z.; Li, Y.; Zhou, X.H.; Guo, X.F.; Zhang, X.G.; Zheng, L.Q.; Li, Y.; Jiao, Y.D.; Sun, Y.X. Association between obesity and ecg variables in children and adolescents: A cross-sectional study. Exp. Ther. Med. 2013, 6, 1455-1462. [CrossRef] [PubMed]

65. Ravisankar, P.; Madanmohan; Udupa, K.; Prakash, E.S. Correlation between body mass index and blood pressure indices, handgrip strength and handgrip endurance in underweight, normal weight and overweight adolescents. Indian J. Physiol. Pharmacol. 2005, 49, 455-461. [PubMed]

66. Nikolaidis, P.T. Elevated body mass index and body fat percentage are associated with decreased physical fitness in soccer players aged 12-14 years. Asian J. Sports Med. 2012, 3, 168-174. [CrossRef] [PubMed]

67. Nikolaidis, P.T. Body mass index and body fat percentage are associated with decreased physical fitness in adolescent and adult female volleyball players. J. Res. Med. Sci. 2013, 18, 22-26. [PubMed]

68. Nikolaidis, P.T. Prévalence du surpoids, et rapport entre l'indice de masse corporelle, le pourcentage de graisse corporelle et la condition physique chez les footballeurs masculins âgés de 14 à 16 ans. Sci. Sports 2013, 28, 125-132. [CrossRef]

69. Nikolaïdis, P.T. Cardiorespiratory power across adolescence in male soccer players. Hum. Physiol. 2011, 37, 636-641. [CrossRef]

70. Nikolaidis, P.T.; Ingebrigtsen, J. The relationship between body mass index and physical fitness in adolescent and adult male team handball players. Indian J. Physiol. Pharmacol. 2013, 57, 361-371. [PubMed]

71. Nikolaïdis, P.T. Physical fitness is inversely related with body mass index and body fat percentage in soccer players aged 16-18 years. Med. Pregl. 2012, 65, 470-475. [CrossRef] [PubMed]

72. Park, J.; Ishikawa-Takata, K.; Lee, S.; Kim, E.; Lim, K.; Kim, H.; Lee, I.S.; Tanaka, S. Comparison of daily physical activity parameters using objective methods between overweight and normal-weight children. J. Sport Health Sci. 2016, 7, 210-217. [CrossRef]

73. Redinger, R.N. Is enhanced energy utilization the answer to prevention of excessive adiposity? J. Ky. Med. Assoc. 2009, 107, 211-217. [PubMed]

74. Clevenger, K.A.; Howe, C.A. Energy cost and enjoyment of active videogames in children and teens: Xbox 360 kinect. Games Health J. 2015, 4, 318-324. [CrossRef] [PubMed]

75. Maffeis, C.; Schutz, Y.; Micciolo, R.; Zoccante, L.; Pinelli, L. Resting metabolic rate in six- to ten-year-old obese and nonobese children. J. Pediatr. 1993, 122, 556-562. [CrossRef] 
76. Lee, S.K.; Nam, S.Y.; Hoffman, D.J. Growth retardation at early life and metabolic adaptation among north korean children. J. Dev. Orig. Health Dis. 2015, 6, 291-298. [CrossRef] [PubMed]

77. Jabbour, G.; O'Loughlin, J.; Sabiston, C.; Tremblay, A.; Mathieu, M.E. Increased lipid oxidation during exercise in obese pubertal girls: A quality study. Obesity 2014, 22, E85-E90. [CrossRef] [PubMed]

78. Rush, E.C.; Plank, L.D.; Davies, P.S.; Watson, P.; Wall, C.R. Body composition and physical activity in new zealand maori, pacific and european children aged 5-14 years. Br. J. Nutr. 2003, 90, 1133-1139. [CrossRef] [PubMed]

79. Rush, E.; Tautolo el, S.; Paterson, J.; Obolonkin, V. Pacific islands families study: Signs of puberty are associated with physical growth at ages 9 and 11 years. N. Z. Med. J. 2015, 128, 24-33. [PubMed]

80. Biro, F.M.; Kiess, W. Contemporary trends in onset and completion of puberty, gain in height and adiposity. Endocr. Dev. 2016, 29, 122-133. [PubMed]

81. Barría, M.A.C.; Valdebenito, M.A.; Filho, Q.J.F. Cardiorespiratory and nutritional status through anthropometric patterns of health in 12-14-year-old schoolchildren in urban and rural areas of the araucanía region, chile. J. Phys. Educ. Sport 2017, 17, 348-354.

82. Navarrete, F.C.; Floody, P.D.; Mayorga, D.J.; Poblete, A.O. Low levels of physical performance, $\mathrm{VO}_{2 m a x}$ and high prevalence of obesity among school children from 9 to 14 years of age. Nutr. Hosp. 2016, 33, 1045-1051.

(C) 2018 by the authors. Licensee MDPI, Basel, Switzerland. This article is an open access article distributed under the terms and conditions of the Creative Commons Attribution (CC BY) license (http:/ / creativecommons.org/licenses/by/4.0/). 